Evolutionary Pathways and Enigmatic Algae:

Cyanidium caldarium (Rhodophyta) and Related Cells 
Developments in Hydrobiology 91

Series editor

H. J. Dumont 


\title{
Evolutionary Pathways and Enigmatic Algae: Cyanidium caldarium (Rhodophyta) and Related Cells
}

\author{
Edited by \\ Joseph Seckbach
}

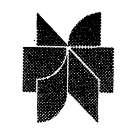

SPRINGER SCIENCE+BUSINESS MEDIA, B.V. 


\section{Library of Congress Cataloging-in-Publication Data}



ISBN 978-94-010-4381-6

Printed on acid-free paper

\section{Cover illustration}

Electron micrograph of Cyanidium caldarium, the predominant staring microalga of this treatise exhibits a dividing cell into two autospores, each cyanidiospore contains a dividing chloroplast (still connected with a Plastid Dividing Ring). We acknowledge Professor T. Kuroiwa (U. of Tokyo) for donating this photo.

\section{All Rights Reserved}

() 1994 Springer Science+Business Media Dordrecht

Originally published by Kluwer Academic Publishers in 1994

Softcover reprint of the hardcover 1st edition 1994

No part of the material protected by this copyright notice may be reproduced or utilized in any form or by any means, electronic or mechanical, including photocopying, recording, or by any information storage and retrieval system, without written permission from the copyright owners. 
This book is dedicated to:

Professor Ikujiro Fukuda (Science University of Tokyo), a professional colleague, supporter, host and catalyst 


\section{Contents}

Foreword by L. Bogorad $\quad$ ix

Preface by J. Seckbach $\quad$ xi

I. Models for the eukaryotic cellular origins and evolutions

Chapter 1. Origin of Eukaryota from cyanobacterium: membrane evolution theory

by $\mathrm{H}$. Nakamura

Chapter 2. Glaucocystophyta model for symbiogenous evolution of new eukaryotic species

by H.E.A. Schenk

Chapter 3. Alternative pathway (cyanobacteria to eukaryota)

by T.E. Jensen

\section{Green enigmatic algae}

Chapter 4. Nanochlorum eucaryotum - a green enigmatic alga: morphology, biochemistry and molecular biology

by R.K. Zahn

Chapter 5 . Enigmatic chlorophycean algae forming symbiotic associations with ciliates

by W. Reisser

\section{The paradoxical Cyanidiophyceae}

The genus Cyanidium

Chapter 6. The natural history of Cyanidium (Geitler 1933: past and present perspectives

by J. Seckbach

Chapter 7. A review on the taxonomic position of the algal genus Cyanidium Geitler 1933 and its ecological cohorts Galdieria Merola in Merola et al. 1981 and Cyanidioschyzon De Luca, Taddei and Varano 1978 by F.D. Ott and J. Seckbach

Chapter 8. Systematic position and phylogenetic status of Cyanidium Geitler 1933 by J. Seckbach and F.D. Ott

Chapter 9. New classification for the genus Cyanidium Geitler 1933

by F.D. Ott and J. Seckbach

Chapter 10. Cyanidium investigations in Japan by I. Fukuda 
Chapter 11. Italy's contribution to the systematics of Cyanidium caldarium 'sensu lato'

by G. Pinto, P. Albertano and A. Pollio

Chapter 12. The study of Cyanidiophyceae in Russia

by O.Y. Sentsova

Chapter 13. Cyanidium-like algae from caves

by L. Hoffmann

Physiology, biochemical pathways and natural products

Chapter 14. The function of peroxisomes in the Cyanidiaceae

by W. Gross

Chapter 15. Nitrogen assimilation in a thermophilic acidophilic alga

by C. Rigano, A. Fuggi, V. Di Martino Rigano and V. Vona

Chapter 16. Natural products of the Cyanidiophyceae

by $\mathrm{H}$. Nagashima

Fine structures of the Rhodophyta and Cyanidium

Chapter 17. Ultrastructure of unicellular red algae

by S.T. Broadwater and J.L. Scott

Chapter 18. Ultrastructure of cytoplasmic organelles in Cyanidium caldarium

by K. Ueda

Chapter 19. Cyanidium caldarium as a model cell for studying division of chloroplasts

by T. Kuroiwa, H. Kuroiwa, T. Mita and N. Ohta

Studies on the molecular level

Chapter 20. Molecular organization and expression of the plastid genome of Galdieria sulphuraria (= Cyanidium caldarium) and other unicellular red algae

by $\mathrm{K}$. Zetsche

Chapter 21. The molecular aspects of pigments and photosynthesis in Cyanidium caldarium

by R.F. Troxler

Bibliographic list of the Cyanidiales and allied enigmatic cells

Chapter 22. List of relevant literature references and index for disciplinary fields

by F.D. Ott and A.J. Petrik-Ott

Appendix. Methods for algal investigation 


\section{Foreword}

I first met Cyanidium caldarium about 35 years ago on the pages of a paper by Mary Belle Allen (Arch. Mikrobiol. 32:207-277, 1959). I knew her as a teaching assistant in the summer microbiology course I had taken at the Hopkins Marine Station taught by C. van Niel. So, in line with the peculiar personal and emotional reactions we have as scientists, I felt a sort of personal connection with $C$. caldarium even before I met it in person. I knew that Mary Belle Allen was a wise and skillful biologist who would discern the truth before sitting down to write about an organism and its habits. Among other virtues, she and Roger Stanier seemed to be the two students who were at that time closest to the great, admirable and very wise van Niel.

C. caldarium seemed to be a wondrous and possibly wonderful organism for certain experiments that I had in mind. At that time I was mostly interested in the biosynthesis of tetrapyrroles, including chlorophylls and the then poorly characterized phycobilins. C. caldarium seemed to have plenty of both and besides it required light for their formation! The latter, together with its facultative heterotrophic nature it grows on $1 \%$ glucose in the dark, made it a good candidate for mutagenesis to isolate mutants with pigment deficiencies, to study action spectra for pigment production, etc. Superimposed on all this was the exotic nature of its habitat: acid hot springs no less! Not all that many organismus would live there (and therefore the contaminants in the laboratory would be likely to be few). Allen (1959) could grow it in $1 \mathrm{~N} \mathrm{H}_{2} \mathrm{SO}_{4}$ in the laboratory. Mary Belle Allen kindly provided a culture and Kenneth E. Nichols, then a graduate student in the laboratory, kindly agreed to work on the organism. I am indebted to C. caldarium for its being the source of interesting questions for many years and to the people who have found fascinating answers.

Some of the questions we had about $C$. caldarium, as we got to know the organism, are reflected in the chapters in this volume. Some questions are answered! Many additional questions, that we didn't know enough to ask or even think about then, have found their places in this volume together with answers in many cases. I am indeed pleased to see questions raised, addressed and answered. The study of C. caldarium has moved through and left a trail of pockets of active research in the fields of evolution, natural history and now on into hot areas of biochemistry and molecular biology. These days it is thought by some that an organism hardly exists as an acceptable research subject unless one of its genomes has been or is being sequenced in its entirety! Even this may not be totally out of sight for the chloroplast genome of $C$. caldarium.

Joseph Seckbach saw other people in the laboratory working on $C$. caldarium when he was a graduate student. He was appropriately fascinated by its strange growth habits as we all were. When Joseph Seckbach became an exo-biologist the scientific environment at UCLA seemed to be a strange enough one for even $C$. caldarium to fit right in. Thus, I have a second debt to $C$. caldarium. It has kept me in closer touch with Joseph Seckbach over the years then I might have been otherwise. My interests shifted although C. caldarium has come back into my scientific life from time-to-time but I knew that I could always find Joe Seckbach near 'our favorite organism'.

Simply by its existance $C$. caldarium has raised many questions about evolution, taxonomy, physiology and molecular biology. Its (sometimes) friendly nature has let it be used by all of us to answer some of these questions. Those of us who have been involved with $C$. caldarium know that others who have not 


\section{x Foreword}

met this alga are missing great opportunities and pleasures. I believe that the authors of all the chapters in this volume hope that the information will be helpful both for those who have been working with the organism and those who have not yet discovered it for themselves.

Harvard University

Lawrence Bogorad

Cambridge, $M A$

January 21, 1994 


\section{Preface}

The origins and evolution of the eukaryotic cell and its organelles has become a major point of interest in modern biology. Currently, there are two principal theories concerning the eukaryogenesis: the classical autoendogenous compartmentalization and the more popular and widely accepted the (Serial) Endosymbiotic theory. Two traditional evolutionists present their view on the direct filiation of the bacterial and blue-green algal (prokaryotic) cell into the nucleated (eukaryotic) organism. The symbiotic speculation is stressed in the chapter of the Glaucocystophyta and is also scattered in the articles throughout this treatise.

The idea of organizing a treatise of a special group of algae and about the evolutionary pathways has been born about a dozen of years ago (see cover illustration of Ann. N.Y.Ac.Sc. 361, 1981). During the recent years the interest in these organisms has increased enormously, hundreds of articles have been published in various journals or books, and a great amount of data has been accumulated and scattered all over the literature (see e.g., the bibliography chapter by Ott and Ott, in this book). However, there has not been a central reference source to present the background and present day picture of these interesting algae.

This treatise presents most of our current state of the art and present day knowledge of these organisms in one volume. It deals with enigmatic algae which indicate unusual features. They exhibit simple level of cellular organization but yet may serve as models for evolutionary pathways and are distinctive in their biochemical and molecular properties. The algal members assigned in this volume are special unicellular aquatic or hydrophilic plants which are important as primary food producers in the food chain, and as oxygen generators for their (cellular) environments. Their global distribution is ubiquitous, however, they are endemic to their characteristic habitats.

The leading algae presented in this text are acido thermophilic organisms, i.e., Cyanidium caldarium (Red alga) and its related algae within the Cyanidiaceae. The other unicellular algae staring in this volume, are some glaucophytes (e.g., Cyanophora paradoxa). They contain cyanobacterium-like 'cyanoplasts' or cyanelles which function as photosynthetic organelles. Therefore, these distinctive algae have been recognized as the classical transitional protistan bridging the blue-green and the eukaryotic algae (see also extended chapter of Schenk in this volume). The green enigmatic micro-algae displayed in this manual are the newly discovered Nanochlorum eucaryotum as well as microscopic unicellular chlorophytes (Chlorella sp.) residing within other protistan single celled animals (ciliates) and surviving in symbiotic relationships with their host cells.

The recent usages of high power tools of molecular biology (for sequencing macromolecules) to detect phylogenetic relationships among various organisms) is also presented with these fascinated algae. In this composition several experts gathered to expose their studies and reviewed their long time investigations with these puzzling algae or on evolutionary speculations. Therefore this book can be considered an authoritative text. It is our hope and expectation that this book will undoubtedly stimulate more interest in the use of these algae as experimental organisms. Indeed these published reference work should be a lasting definitive scientific contribution to our knowledge of $C$. caldarium and its enigmatic allied.

This collection of enigmatic algal essays involved multi-disciplinary studies. We discuss and present fields of ultrastructure, cytology, physiology and biochemistry, molecular sequencing, as well as taxonomic and a new proposed classification of these organisms. It is our expectation that this treatise will assist graduate students, researchers or lecturers of natural and life sciences in their investigations. 
Our present guidebook may well circulate in harmony with the recently new books dealing with Algae and Symbioses (1992; ed. Reisser, W. Biopress, Bristol, England), Symbiosis in Cell Evolution (1981, Margulis, L. Freeman \& Comp. San Francisco), Five Kingdoms (1988, Margulis, L. and Schwartz, K.V. Freeman and Comp. N.Y.) or the proceedings of the Endocytobiology Colloquia (I and II eds. Schwemmler W. and Schenk, H., 1980 and by Schenk, H. and Schwemmler, W. 1983, both published by W. de Gruyter, Berlin; III, eds. Lee, J.J. and Fredrick, J.F. see New York Acad. Sci. 503, 1987; IV, eds. Nardon, P. et al. 1990, INRA, Paris; V, eds. Sato et al. 1993. Tübingen U. Press, Tübingen).

Finally, I would like to thank all people who carried with me the investigations of these fascinating cells and their evolutionary hypotheses. Special appreciations are due to Prof. Ikujiro Fukuda (Sci. U. of Tokyo) for initial encouragement and support, and to our contributors for their chapters and patience.

Hebrew University of Jerusalem

Joseph Seckbach

Mount Scopus, Jerusalem, Israel

April 15, 1994

Note: We use the 'short style' of references because the full bibliographic list of Ott and Ott (in this volume) contains a detailed information of most citations. 